\title{
SERVICE PROCESSES ARCHITECTURE IDENTIFICATION AT THE FINANCIAL AND ACCOUNTING SHARED SERVICES CENTRE
}

\author{
Piotr SLIŻ ${ }^{1 *}$, Martyna BRENNENSTUHL ${ }^{2}$ \\ ${ }^{1}$ University of Gdańsk; piotr.sliz@ug.edu.pl, ORCID: 0000-0001-6776-3369 \\ ${ }^{2}$ martyna.brennenstuhl@gmail.com \\ * Correspondence author
}

Purpose: The basic aim of the article was to recreate the service processes architecture in the selected financial and accounting shared services centre. Two auxiliary goals (CC) have been assigned to this goal. CC1: Approximation and definition of the current state of knowledge regarding process management on the example of SSC providing accounting and financial services. CC2: Characterization of inputs, outputs and goals for the identified activities in the main service processes in the studied SSC organization.

Design/methodology/approach: The following research methods were used to achieve the stated goals: quantitative bibliometric analysis, systematic literature review, statistical methods (LOESS analysis), participant observation and unstructured interview. The R programming language was used in the analysis of time series in the theoretical study.

Findings: As a result of the study, the main service processes in the examined organization were identified and recreated, and their goals, inputs, outputs and sets of implemented activities were determined. On this basis, a reproduced map of selected main processes is presented, taking into account the course of activities between them. This article supplements the knowledge on the issues of service processes management in an organization identified as SSC and can set the research framework for subsequent empirical proceedings regarding the examination of the level of maturity of selected processes, the level of implementation of process orientation in SSC, as well as attempting to use the generated event logs database for exploration of processes and comparing their course with reference models.

Research limitations/implications: The limitations of the presented article result from the presentation of the example of one shared service centre in Poland and a limited group of respondents who, due to the data security policy in the examined organization, could take part in the study. This prevented, among others, detailed characterization of management processes and support processes related to administration, controlling, accounting, human resources and IT.

Practical implications: The results presented in this article have an application value related to the map of the main SSC service processes presented, which can be discounted both by the SSC management staff and process owners in the SSC design space, measurement of processes and identification of customer-supplier relations in external and internal terms. 
Originality/value: The article fills the cognitive gap related to the lack of reconstruction studies, using the observation and interview method, the structure of main and auxiliary service processes in SSC, which is the basis for further research in the field of formalization, exploration, measurement and management of identified processes.

Keywords: BPM, Business Process Management, Process orientation, Shared Service Centre, SSC, CUW.

Category of the paper: Research paper.

\section{Introduction}

Dynamic changes in the competitive environment of contemporary international enterprises in the private sector, as well as organizations operating in the public sector, are the starting point for seeking solutions that enable cost reduction and focus on activities aimed at increasing the level of standardization of business processes. This, in turn, is an incentive to search, using modern information and communication technologies, solutions enabling robotization and automation of service processes with a high degree of repeatability and standardization. An example of such organizations are the shared service centre (CSS), which both in Poland and in the world have an increasing share as employers. At this point it should be emphasized that the importance of Poland in Europe on the SSC market is significantly increasing. According to a report prepared by Deloitte, Poland was classified second to India in the strategic location assessment category (Deloitte, 2019). The selection of location is determined by factors such as the availability of research centres, communication by air, land and sea. In Poland, the most visible development in terms of the number of employees, as well as new CSS is identified in the Tri-City, Warsaw, Kraków, Wrocław, Lodz and Bydgoszcz.

The increase in both the number of this type of organizations and the employees employed in the shared service centre requires a look from the perspective of management sciences and quality on this type of organization in the space of business processes, human resource management, business models, as well as the possibility of implementing modern technological solutions and IT tools, such as: artificial intelligence (AI), robotics process automation (RPA), process-mining, data-mining, as well as augmented reality. Despite the increasing share of SSC on the international market, the lack of description of this problem in both the epistemological and empirical part has been confirmed in the literature on the subject (Richter and Brühl, 2017).

The main axis of this article was to recreate the service processes architecture in the selected financial and accounting shared service centre in Poland. Two auxiliary goals (CC) have been assigned to this goal. CC1: Approximation and definition of the current state of knowledge regarding process management on the example of SSC providing accounting and financial services. CC2: Characterization of inputs, outputs and goals for the identified activities in the main service processes in the SSC organization under study. 


\section{Theoretical background}

\subsection{Quantitative bibliometric analysis}

The theoretical study began with a quantitative bibliometric analysis based on the resources of the Web of Science Core Collection (WoS) database. The summary and search criteria are described in Table 1. The results of this part of the analysis are based on the WoS search engine in the topic category, in all Web of Science category databases.

Table 1.

List of bibliometric indicators for studied entries in the WOS database

\begin{tabular}{|c|c|c|c|c|c|c|}
\hline Entry/entries & $\begin{array}{c}\text { Years of } \\
\text { publications }\end{array}$ & $\begin{array}{c}\text { Total } \\
\text { publications }\end{array}$ & $\begin{array}{c}\text { Sum of } \\
\text { times cited }\end{array}$ & $\begin{array}{c}\text { Citing } \\
\text { articles }\end{array}$ & $\begin{array}{l}\text { Average } \\
\text { citations } \\
\text { per item }\end{array}$ & h-index \\
\hline $\begin{array}{l}\text { "shared service centre" } \\
\text { OR "shared service } \\
\text { centres" }\end{array}$ & $2007-2020$ & 71 & $\begin{array}{r}392 * / \\
337 * *\end{array}$ & $\begin{array}{r}320 * / \\
291 * *\end{array}$ & 5.52 & 10 \\
\hline $\begin{array}{l}\text { "shared service centre" } \\
\text { OR "shared service } \\
\text { centres" }\end{array}$ & $1976-2020$ & 258 & $\begin{array}{r}1,688 * / \\
1,465 * *\end{array}$ & $\begin{array}{r}1,411 * / \\
1,342 * *\end{array}$ & 6.54 & 20 \\
\hline $\begin{array}{l}\text { ("shared service centre" } \\
\text { OR "shared service } \\
\text { centres") AND "process" }\end{array}$ & $2000-2020$ & 51 & $\begin{array}{r}288 * / \\
279 * *\end{array}$ & $\begin{array}{l}266 * / \\
263 * *\end{array}$ & 5.65 & 10 \\
\hline
\end{tabular}

Source: own study based on the WoS database, access: 08.01.2020.

In turn, Figure 1 illustrates the detailed data on both researched scientific parameters.
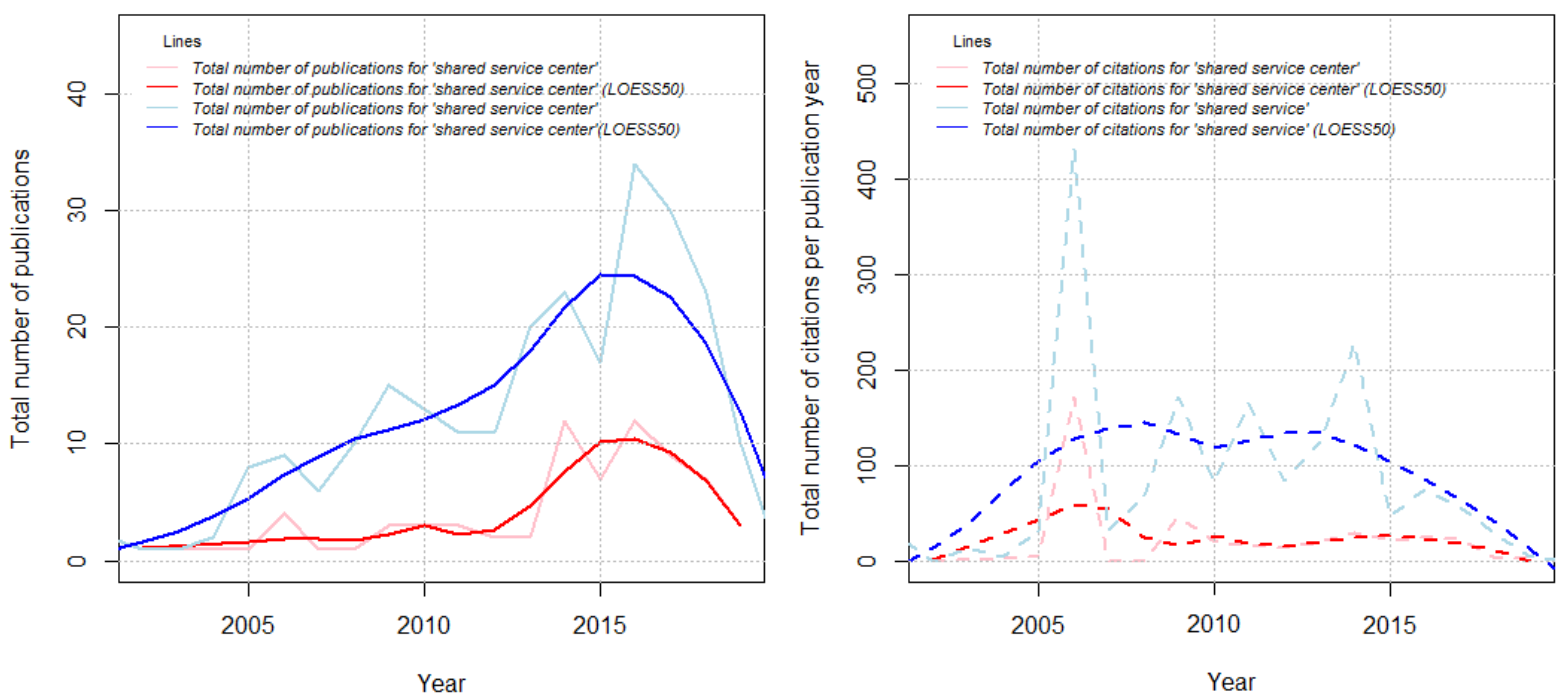

Figure 1. Compatison of the number of publications and the number of citations for the entries 'shared service centre' and 'shared service' based on data generated in the Web of Science database. Source: own study using the R programming language based on the WoS database, access: 08.01.2020.

The analysis of time series containing the number of publications and their citations in the function pf years of publication was carried out using non-parametric locally weighted regression identified in the literature with the LOESS abbreviation (Cleveland and Devlin, 
1988). Its possibilities of application in the assessment of time series, as well as the advantages and limitations of its use have been described in (Poniat, 2016).

Based on the obtained summary data on the examined bibliometric parameters, it was noticed that the issue of shared service centres in the discipline of management and quality sciences has been raised more and more often since 2005, with particular emphasis on 20142017. The analysis of the WoS database resources has provided evidence that 'shared service' is a much capacious term containing the issues described in this article. The number of publications in the function of the studied time series increased with similar dynamics. In addition, it should be clearly emphasized that from the perspective of the parameter number of citations of published studies, most often cited were the ones published in 2006-2014. In the authors' opinion, the level of interest in the literature on the subject presented in this way may be determined by the limited access to research in this type of organization, resulting from SSC internal policies (Figure 1).

\subsection{Systematic review of the literature on the subject}

First, based on the article indexed in WoS, a review of the definition of the term 'shared service' was carried out (Table 2).

Table 2.

Characteristics of selected definitions for the 'shared service' entry

\begin{tabular}{|l|l|}
\hline \multicolumn{1}{|c|}{ Author } & \multicolumn{1}{c|}{ Definition } \\
\hline (Bergeron, 2002, p. 3) & $\begin{array}{l}\text { "Shared services is collaborative strategy in which a subset of existing business } \\
\text { functions are concentrated into a new, semiautonomous business unit that has } \\
\text { a management structure designed to promote efficiency, value generation, cost } \\
\text { savings, and improved service for the internal customers of the parent } \\
\text { corporation, like a business competing in the open market". }\end{array}$ \\
\hline $\begin{array}{l}\text { (Wang, S. and Wang, H., } \\
\text { 2007, p. 281) }\end{array}$ & $\begin{array}{l}\text { "Shared service is the standardization and consolidation of common functions } \\
\text { across multiple organization to reduce information process duplication and } \\
\text { increase information and knowledge sharing. Shared services tend not to be } \\
\text { perceived as just another example of the alliance of business and the information } \\
\text { technologies. Instead, the cross-organizational dimension of shared services } \\
\text { makes up distinctive characteristics in contrast to other applications of } \\
\text { information technology to business" }\end{array}$ \\
\hline
\end{tabular}

Source: own study based on the indicated literature on the subject.

In turn, Table 3 presents selected characteristics of concepts for the subject in the quantitative bibliometric analysis of the entry 'shared service centre' (SSC) (Table 3).

Table 3.

Characteristics of selected definitions for the entry 'shared service centre'

\begin{tabular}{|c|c|}
\hline Author & Definition \\
\hline $\begin{array}{l}\text { (Schultz and Brenner, } \\
2010 \text {, p. 217) }\end{array}$ & $\begin{array}{l}\text { "SSC is an organizational concept that consolidates processes within the group } \\
\text { in order to reduce redundancies; delivers support processes; has cost cutting as a } \\
\text { major driver; that has a clear focus on internal customers; is a separate } \\
\text { organizational unit that is aligned with external competitors and is operated like } \\
\text { a business" }\end{array}$ \\
\hline
\end{tabular}


Cont. table 3.

\begin{tabular}{|c|c|}
\hline $\begin{array}{l}\text { (Rothwell, Herbert and } \\
\text { Seal, 2011, p. 243) }\end{array}$ & $\begin{array}{l}\text { "An emerging alternative to outsourcing is the shared service centre (SSC) in } \\
\text { which activities previously located in business units or head office are retained } \\
\text { within the organization but aggregated into a new central unit, operating at arms' } \\
\text { length from the mother organization in a quasi-market manner [...]". (p. 243) }\end{array}$ \\
\hline $\begin{array}{l}\text { (Wagenaar et al., 2006, } \\
\text { p. 144) }\end{array}$ & $\begin{array}{l}\text { "SSCs are a promising concept that can lead to better and cheaper service- } \\
\text { rendering and more effective knowledge management". }\end{array}$ \\
\hline $\begin{array}{l}\text { (Herbert and Seal, 2016, } \\
\text { p. 134) }\end{array}$ & $\begin{array}{l}\text { "While usually predicated on cost reduction, the shared service centre (SSC) is } \\
\text { an alternative approach whereby the noncore support activities are taken out of } \\
\text { business divisions and consolidated in a new unit with a separate "arm's length" } \\
\text { management structure, typically at a new and lower cost location". }\end{array}$ \\
\hline
\end{tabular}

Source: own study based on the indicated literature.

In the context of the SSC studied organizations, P.C. Richter and R. Brühl identified 17 main areas for future research into the issues under consideration. Noteworthy are the three main potential directions of implementation of empirical proceedings, among which the following were qualified: direct relationships, mediating, and outcome effects, regarding SSCs during their operational maturity phase (2017). In turn, A.T. Rothwell, I.P. Herber and W. Seal attempted to examine SSC as a new organizational form that could lead to fundamental changes in the nature and location of professional work (2011). Another article addresses significant problems arising from the level of standardization of activities in processes at the SSC taking into account the level of employee qualifications and activities of a routine nature. The study shows how this ongoing process is full of contradictions, problematically depicting people and placing auxiliaries (Howcroft and Richardson, 2012).

In the literature on the subject, SSC-related issues were discussed in the space of characteristics of introduction motives and SSC characteristics on the example of public administration (Janssen and Joha, 2006, Hawrysz, 2015). In the public sector accounting space based on the theoretical discussion, an innovative typology of various SSCs and modes of their creation was presented, as well as the challenges that these specific models have to face were outlined (Raudla and Tammel, 2015). The need for a much more detailed view of the organization was proved by the study carried out on the selected SSC, which aimed to assess the level of implementation of process orientation in the organization from the perspective of management and implementers of various main processes (Sliż, Brennenstuhl, 2019). Also noteworthy is the study raising the problem of innovation in shared services related to design (creation) and SSC functioning (Szukalski, 2012). The results of the literature review also highlighted the importance of publications on the identification of processes in organizations other than SSC, as well as methods of their identification (Biesok, 2010). Such attempts were made on the example of organizations in terms of the value chain (Czakon, 2001), supply chain (Jokiel, 2014), processes on the example of construction (Polak, 2010), as well as in the space of management processes (Dziembek, 2011). 
To sum up, as a result of the theoretical study, a cognitive gap was identified consisting of a small number of publications characterizing the functioning of shared service centres and the identification of processes occurring in them. The indicated gap is confirmed by P.C. Richter and R. Brühl (2017) in their paper, who also indicated that the topic of SSC was presented in a small number of publications, and the described problems have a wide research potential.

\section{Materials and methods}

\subsection{Project of empirical proceedings}

Empirical proceedings were carried out on a sample of a selected financial shared services centre in Poland. The study was divided into five successive stages.

- Stage 1 - implementation of the theoretical study using quantitative bibliometric analysis and a semantic review of the literature on the subject.

- Stage 2 - identification of cognitive gaps and formulation of research goals.

- Stage 3 - selection of the studied unit and observation project.

- Stage 4 - analysis of documents and implementation of participant observation.

- Stage 5 - analysis of the results obtained and formulation of conclusions.

The proceedings were carried out using the method of participant observation and unstructured interview in the second half of 2019.

\subsection{Characteristics of the studied organization}

The subject of the empirical proceedings described in the article was a separate part of an international organization with foreign capital identified on the basis of literature as a shared services centre (SSC) based in Poland. This means that the studied unit is only a separate part of the supranational organization and is subject to the area of accounting and financial activities of the company. Figure 2 shows a simplified structure of the main and auxiliary processes in the examined SSC. At this point it should be emphasized that the organization has identified an organizational matrix structure with the indication that process owners and the GPO area are located at the headquarters of the organization outside the structure of the described SSC.

From the perspective of the analysis of the assessment of the process orientation level, ISO 9001 and ISO 22301 certificates have been implemented. It should be understood that in the organization, services processes are identified and formalized in the form of process maps available on the inner Internet for all process implementers. 


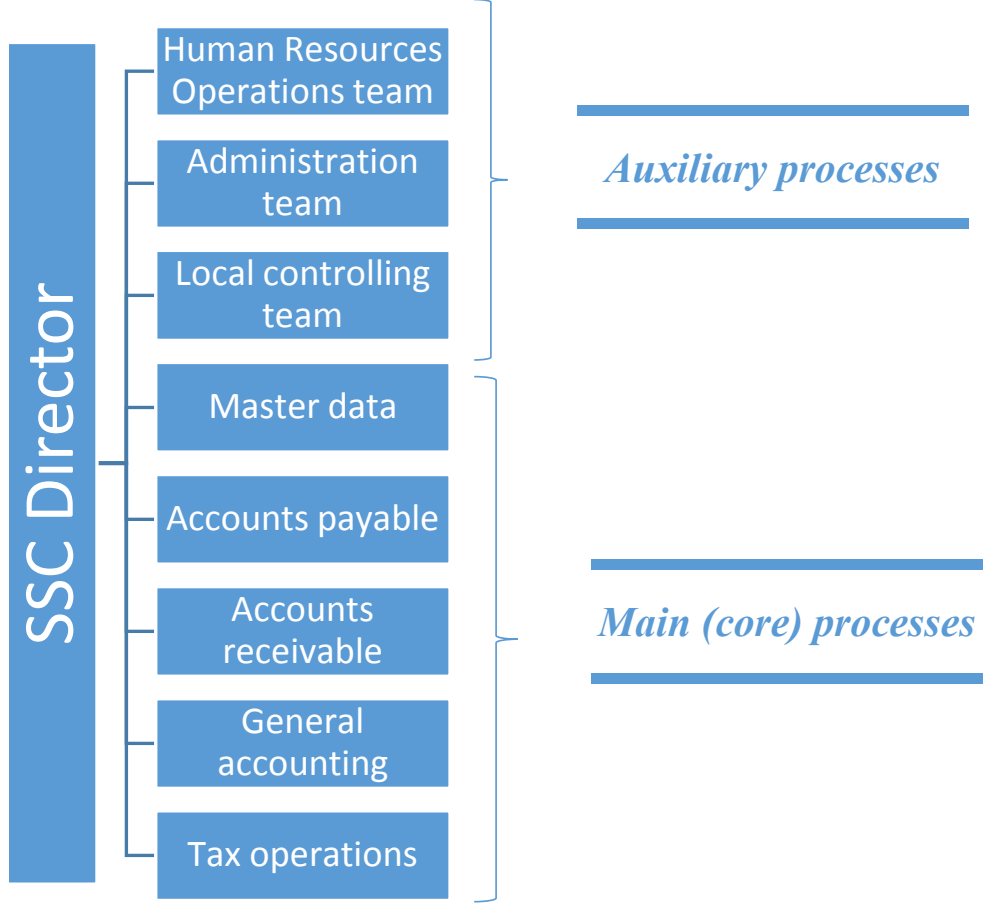

Figure 2. A simplified structure of processes in the studied SSC. Source: own study based on the study carried out in 2019.

\section{Results}

In the first stage of the research procedure, based on the documentation and interviews with employees, the reconstructed sets of activities were classified into main and auxiliary processes (Figure 2). The group of main processes includes: master data (MD), accounts payable (AP), accounts receivable (AR), general accounting (GA) and tax operations (TO). In turn, the identified support processes are: human resources (HR), administration (ADM), local controlling (LC) and IT support (IT). At this point it should be emphasized that limited access to information has made it possible to reconstruct the stages of implementation of only main processes (Figure 3). 


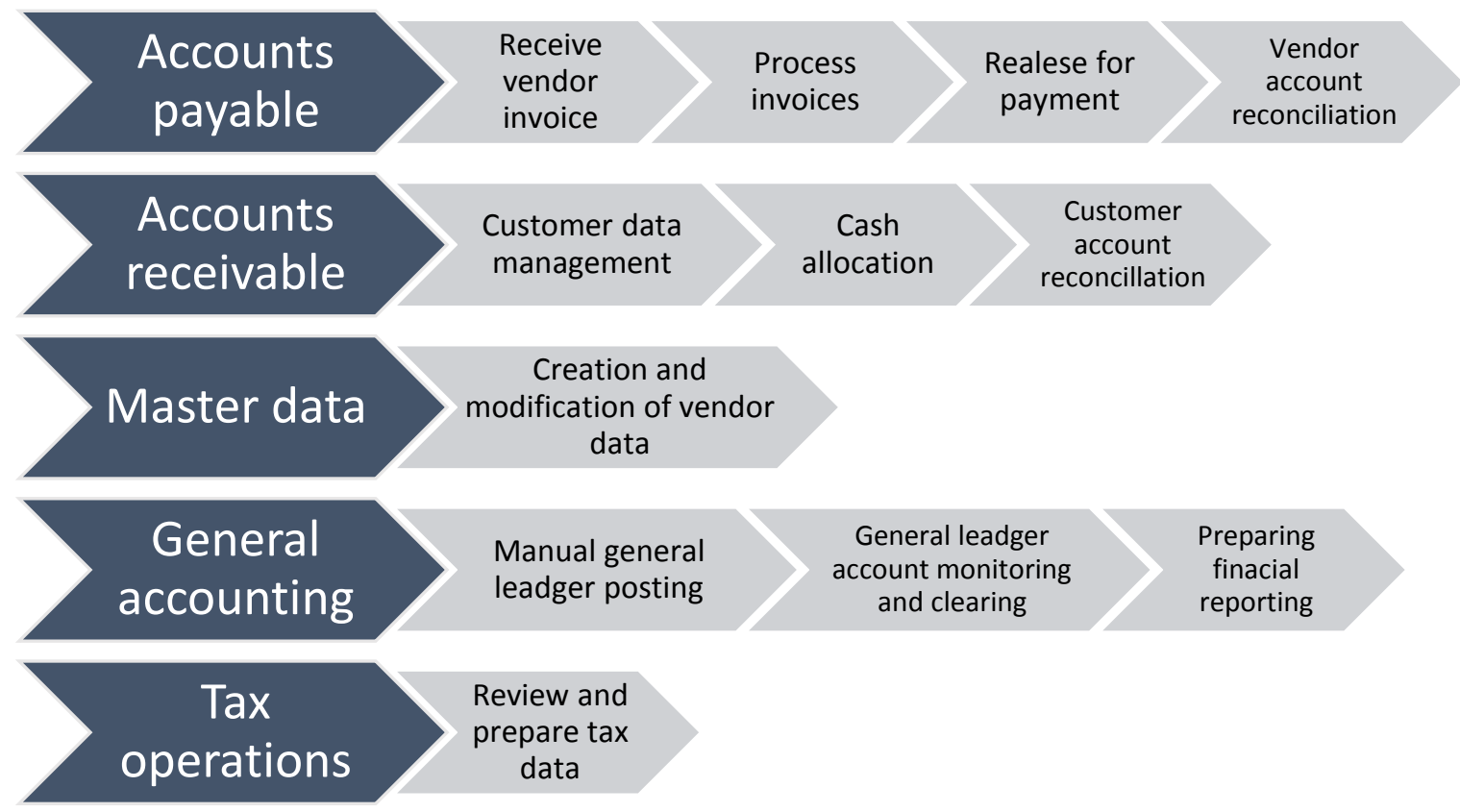

Figure 3. List of stages of the identified main services processes in the examined SSC. Source: own study based on the study carried out in 2019 .

Subsequently, as a result of interviews and analysis of maps of the course of the main processes presented in Figure 3, an attempt was made to identify, based on the assumptions of SIPOC/COPIS conventions, the inputs and outputs, and the activities implemented in them. The results of this part of the procedure are presented in Table 4.

Table 4.

Characteristics of inputs and outputs in main processes in the examined SSC

\begin{tabular}{|c|c|c|c|}
\hline Process name & Input & Activities implemented in the process & Output \\
\hline \multirow{2}{*}{ Master data } & \multirow{2}{*}{$\begin{array}{c}\text { Receive creation/ } \\
\text { modification request }\end{array}$} & Master data verification & \multirow{2}{*}{$\begin{array}{l}\text { Vendor/ customer account } \\
\text { creation/ modification }\end{array}$} \\
\hline & & Master data entry & \\
\hline \multirow{3}{*}{$\begin{array}{l}\text { Accounts } \\
\text { payable }\end{array}$} & \multirow{3}{*}{$\begin{array}{l}\text { Receive vendor } \\
\text { invoice }\end{array}$} & Approval initiation & \multirow{3}{*}{ Vendor account clearing } \\
\hline & & Invoice posting & \\
\hline & & Vendor accounts analysis & \\
\hline \multirow{3}{*}{$\begin{array}{l}\text { Accounts } \\
\text { receivable }\end{array}$} & \multirow{3}{*}{$\begin{array}{c}\text { Receive incoming } \\
\text { payment }\end{array}$} & Handle mismatches & \multirow{3}{*}{$\begin{array}{l}\text { Customer account } \\
\text { clearing }\end{array}$} \\
\hline & & Perform dunning & \\
\hline & & Allocate incoming payment & \\
\hline \multirow{3}{*}{$\begin{array}{c}\text { General } \\
\text { accounting }\end{array}$} & \multirow{3}{*}{$\begin{array}{l}\text { Entries on GL } \\
\text { accounts }\end{array}$} & Monitoring and clearing on GL accounts & \multirow{3}{*}{$\begin{array}{l}\text { GL accounts closing and } \\
\text { reporting }\end{array}$} \\
\hline & & GL closing activities & \\
\hline & & Reporting activities & \\
\hline \multirow{3}{*}{ Tax operations } & \multirow{3}{*}{$\begin{array}{l}\text { Entries on tax } \\
\text { accounts }\end{array}$} & Posting review on tax accounts & \multirow{3}{*}{ Posting correction report } \\
\hline & & Verification of tax data on the invoice & \\
\hline & & Formal/ fiscal/ error posting check & \\
\hline
\end{tabular}

Source: own study based on the study carried out in 2019.

Based on the identified auxiliary processes, it was observed that the activities are implemented in them by the appointed team. Noteworthy is the human resources operations team, which scope of implemented activities indicates that it should be treated as an interdisciplinary team. Characteristics of activities carried out by human resources, administration, controlling and IT support processes are presented in Figure 4. 


\begin{tabular}{|l|}
\hline $\begin{array}{c}\text { Human Resources } \\
\text { Operations Team }\end{array}$ \\
\hline -talent acquisition \\
- execution of \\
recruitment \\
-conducting \\
trainings \\
-employment \\
administration \\
-international \\
mobility \\
-time management \\
-payroll service \\
-compensation \& \\
benefit \\
\hline
\end{tabular}

\begin{tabular}{|l|}
\hline \multicolumn{1}{|c|}{$\begin{array}{c}\text { Administration } \\
\text { Team }\end{array}$} \\
\hline -supporting SSC in \\
all administrative \\
areas \\
-reception support \\
- maintaining and \\
servicing office \\
equipment \\
- managing facility \\
- controlling and \\
reporting of sales \\
for Accounting \\
Services \\
\end{tabular}

\begin{tabular}{|l|}
\hline \multicolumn{1}{|c|}{ Controlling Team } \\
\hline -preparation of \\
budgets, forecasts \\
and reporting \\
-costs analysis and \\
reporting \\
-controlling and \\
reporting of sales \\
for Accounting \\
Services \\
-reporting of \\
projects \\
\end{tabular}

\begin{tabular}{|l|}
\hline \multicolumn{1}{|c|}{ IT Team } \\
\hline -maintenance and \\
service of technical \\
infrastructure and \\
IT security \\
-internal customer \\
service \\
-IT consulting \\
\\
\hline
\end{tabular}

Figure 4. Characteristics of activities implemented by the support process teams in the examined SSC. Source: own study based on the study carried out in 2019.

As a result of the synthesis of parameters (inputs, actions and outputs) for a group of five main processes (Figure 3), a map of their course in the examined organization was created. Figure 4 shows the sequence of actions implemented in the main processes.

At this point it should be emphasized that the course of activities in the main service processes in the restored architecture presented in Figure 5 is consistent with the internal documentation of the organization. This means that no significant differences between process maps and information on the course of activities from their implementers were noticed. 


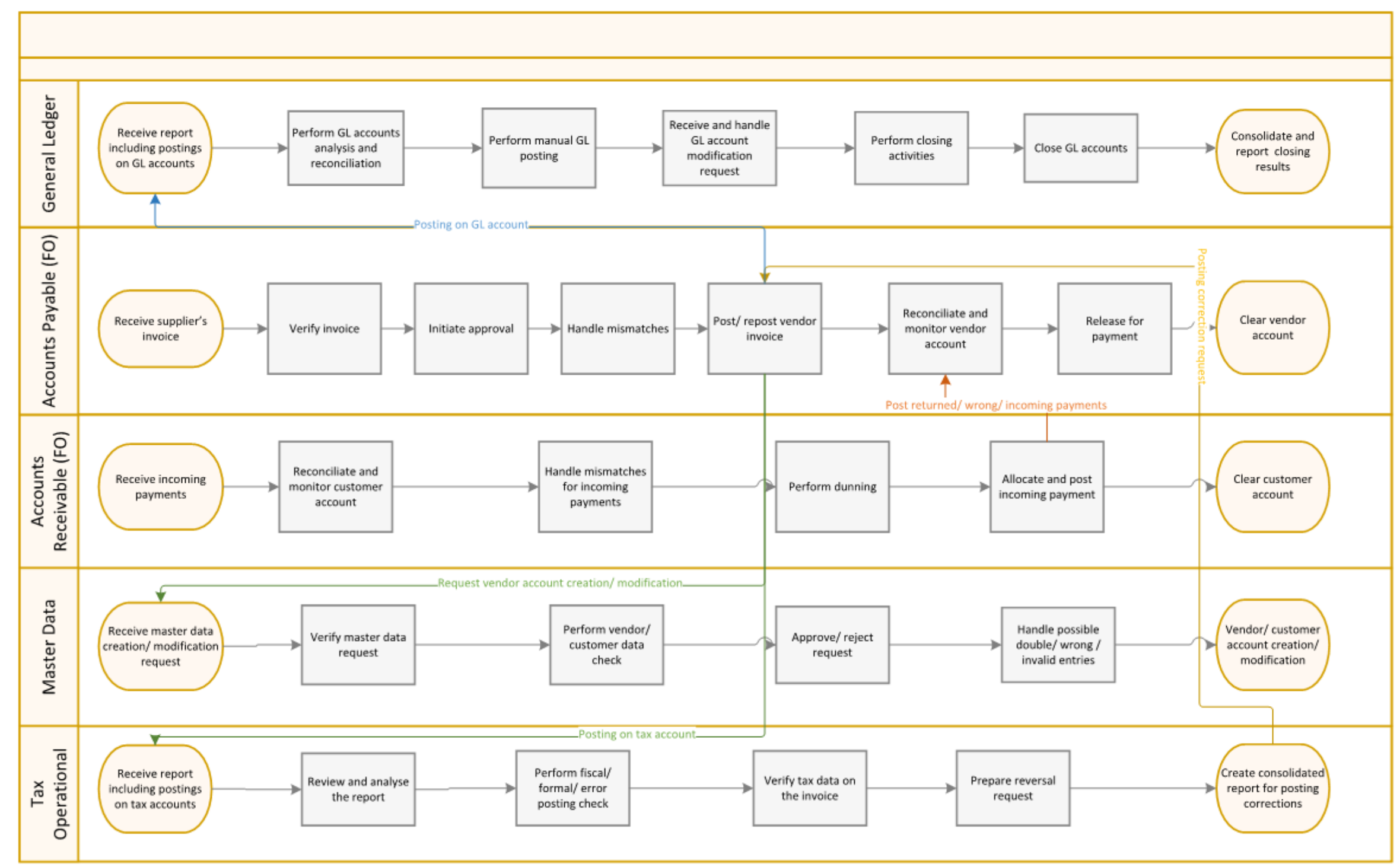

Figure 4. Architecture of the main service processes in the examined SSC. Source: own study based on the study carried out in 2019. 


\section{Discussion and conclusion}

Completed research using the method of participant observation and unstructured interview enabled the formulation of several general conclusions.

First of all, as a result of the conducted research procedure, the course of five main service processes was identified and reconstructed, including the general ledger, accounts payable, accounts receivable, master data and tax operations. In the examined SSC, the business processes characterized in Figure 5 are identified, formalized, measured and managed, and there are symptoms confirmed during the study that testify for their improvement, which includes not only process owners or management staff, but also process implementers. As a result of observing the documentation of the course of selected service processes, it should be emphasized that they have a laminar character, while the implemented activities are characterized by a high level of standardization and are recorded in the form of precise algorithms of conduct on which course the contractor has a limited impact. This means that the high share of procedures in the described processes also indicates their rigidity. In addition, the implementation of the SAP system enables the generalization of event sets during implemented processes, which is the starting point for the use of modern technologies and tools, such as process-mining and robotic process automation (RPA). At this point it should be clearly indicated that the structure of the main processes presented in this article applies only to the examined SSC, and not to the entire organization for which the described main processes are identified as auxiliary processes.

To sum up, it should be clearly emphasized that from the perspective of research on process management issues, as well as the implementation of the level of process orientation, organizations identified as SSC are research material in the space of such issues as: assessment of process maturity, reconfiguration of organizational structures from matrix and process into process-design, as well as the assessment of the level of process and design orientation.

\section{References}

1. Bergeron, B. (2002). Essentials of shared services (Vol. 26). John Wiley \& Sons.

2. Biesok, G. (2010). Metody identyfikacji procesów w organizacji. Problemy Jakości, 5, 2-6.

3. Cleveland, W.S., \& Devlin, S.J. (1988). Locally weighted regression: an approach to regression analysis by local fitting. Journal of the American statistical association, 83(403), 596-610. 
4. Czakon, W. (2001). Identyfikacja procesów w firmie w aspekcie łańcucha wartości. Przegląd Organizacji, 2, 21-27.

5. Dziembek, D. (2011). Identyfikacja procesów zarządzania wiedzą w organizacji wirtualnej. Zeszyty Naukowe Uniwersytetu Szczecińskiego. Ekonomiczne Problemy Ustug, 68, Drogi dochodzenia do społeczeństwa informacyjnego: stan obecny, perspektywy rozwoju i ograniczenia. T. 2, 484-492.

6. Farndale, E., Paauwe, J., \& Hoeksema, L. (2009). In-sourcing HR: shared service centres in the Netherlands. The International Journal of Human Resource Management, 20(3), 544-561.

7. Hawrysz, L. (2015). Centra usług wspólnych w sektorze publicznym w Polsce. Ekonomika i Organizacja Przedsiębiorstwa, 5, 50-57.

8. Herbert, I., \& Seal, W. (2014). A knowledge management perspective to shared service centres: A case study of a finance SSC. Shared Services as a New Organizational Form, 133-151.

9. Hoła, B., Gawron, K., Polak, A., \& Sawicki, M. (2012). Identyfikacja procesów zarządzania w przedsiębiorstwie budowlanym. Przegląd Budowlany, 83, 59-62.

10. Howcroft, D., \& Richardson, H. (2012). The back office goes global: exploring connections and contradictions in shared service centres. Work, Employment and Society, 26(1), 111-127.

11. Janssen, M., \& Joha, A. (2006). Motives for establishing shared service centres in public administrations. International Journal Of Information Management, 26(2), 102-115.

12. Jokiel, G. (2014). Identyfikacja procesów w łańcuchach dostaw. Research Papers of the Wroclaw University of Economics/Prace Naukowe Uniwersytetu Ekonomicznego we Wroclawiu, 340.

13. Kabalski, P., \& Przygodzka, W. (2017). Osobowość zawodowa, środowisko zawodowe i zadowolenie z pracy na przykładzie centrum usług księgowych. Zeszyty Teoretyczne Rachunkowości, 95(151), 31-40.

14. Łada, M., \& Konieczny, A. (2015). Rozwój kariery zawodowej księgowego w centrach usług wspólnych. Studia Ekonomiczne, 245, 142-151.

15. Maatman, M., Bondarouk, T., \& Looise, J.K. (2010). Conceptualising the capabilities and value creation of HRM shared service models. Human Resource Management Review, 20(4), 327-339.

16. Polak, A. (2010). Metody identyfikacji procesów w budownictwie. Przegląd Budowlany, 81(12), 52-55.

17. Poniat, R. (2016). O możliwości wykorzystania regresji LOESS w analizie szeregów czasowych. Przeszłość Demograficzna Polski, 38(2), 104-115.

18. Raudla, R., \& Tammel, K. (2015). Creating shared service centres for public sector accounting. Accounting, Auditing \& Accountability Journal. 
19. Richter, P.C., \& Brühl, R. (2017). Shared service centre research: A review of the past, present, and future. European Management Journal, 35(1), 26-38.

20. Rothwell, A.T., Herbert, I.P., \& Seal, W. (2011). Shared service centres and professional employability. Journal of Vocational Behavior, 79(1), 241-252.

21. Rothwell, A.T., Herbert, I.P., \& Seal, W. (2011). Shared service centres and professional employability. Journal of Vocational Behavior, 79(1), 241-252.

22. Schulz, V., \& Brenner, W. (2010). Characteristics of shared service centres. Transforming Government: People, Process and Policy, 4(3), 210-219.

23. Sliż, P., \& Brennenstuhl, M. (2019). Assessment of the process maturity of the organization on the example of the shared services centre-a case study. Zeszyty Naukowe Politechniki Śląkiej. Organizacja i Zarzadzanie, 136.

24. Szukalski, S.M. (2012). Procesowe $i$ organizacyjne innowacje $w$ centrach ustug wspólnych.

25. Wagenaar, R., Matthijsse, R., de Bruijn, H., van der Voort, H., \& de Joode, R.V.W. (2006). Implementation of shared service centres in public administration: Dilemmas and tradeoffs. Information and communication Technology and Public Innovation, 12, 141-158.

26. Wang, S., \& Wang, H. (2007). Shared services beyond sourcing the back offices: Organizational design. Human Systems Management, 26(4), 281-290.

27. Zarzycka, E., \& Michalak, M. (2013). Centra usług wspólnych (SSC) jako forma organizacji procesów rachunkowości - wyzwania dla praktyki i badań naukowych. Studia i Prace Kolegium, 183. 